\title{
Loyal soldiers or seasoned leaders? The selection of committee chairs in the European Parliament
}

\author{
Mihail Chiru, Oxford School of Global and Area Studies, Oxford, UK
}

\begin{abstract}
Although European Parliament committee chairs play a salient role in the legislative process of the EU, we know virtually nothing about their selection and whether policy specialization and the individual attributes of the MEPs matter in the process. This paper draws on a unique longitudinal dataset that includes all full committee members, information on their past committee experience and office in the first seven terms of the EP and data on their parties. Despite the complex proportionality rules that govern the selection of committee chairs in the EP and the interdependence between their distribution and the allocation of other legislative offices, I find that chair seniority shapes the nomination of committee chairs. On the contrary, there is no evidence that European Party Groups use chair selection to reward their most loyal members, while EPG leaders did become chairs more often than regular members in the early terms.
\end{abstract}

\section{Keywords}

committees; European Parliament; legislative organization; parties; seniority.

Date of acceptance: 21.03 .2019 


\section{Introduction}

In the European Parliament (EP), committee chairs have the power to shape the committee agenda, they solve jurisdictional disputes in their monthly meeting and receive a large number of rapporteurships (Yoshinaka et al 2010; Hurka and Kaeding 2012: 520). Many MEP surveys (Hix et al 2016) have shown that this position is one of the most appealing for Members of the European Parliament (MEPs). Committee chairs have become more important with time, particularly since the creation of the Conference of Committee Chairs.

As Hix and Høyland (2014: 600) have argued, 'although there is some evidence of a seniority effect in the allocation of committee chairs and reports, the precise operation of such a system, if it really exists, has not been convincingly established... our knowledge of how committee chairs are allocated barely moves beyond the proportionality principle between political groups and national delegations within them'. Thus, while past descriptive research has depicted the formal allocation of committee chairs between European Party Groups (EPGs) and national delegations within them, we know virtually nothing about how committee chairs are selected and whether committee seniority and chair seniority influence their selection. The only partial exceptions (Bowler and Farrell 1995; Whitaker 2011) conflated in their analyses the selection of chairs with that of deputy chairs and focused only on one or two terms. 
This paper draws on a unique longitudinal dataset that includes all full committee members, information on their past committee experience and office in the first seven terms of the EP (1979-2014), and data on their parties and national delegations. Our theoretical expectations are derived mostly from congressional theories of committee leadership and are tested using a series of fixed effects conditional logit models. The analyses also differentiate between committee chair selection in powerful committees those with high legislative output or budgetary powers - and less powerful committees. The article tests whether the selection of committee chairs is another case emphasizing the mutual reinforcement of the informational logic of committee policy-making in the EP and the logic of partisan coordination. ${ }^{1}$ Thus, given the relevance of these two logics and the virtual absence of an electoral connection in the EP it would be puzzling if MEPs appointed as chairs would not hold on average more expertise, seniority and stronger partisan credentials than their colleagues.

Moreover, by adopting a longitudinal perspective, the paper can answer the question whether the growth in the legislative role of the EP, and in the importance of committee chairs, has also brought about an increase in the value of committee specialization and chair seniority for appointment to this office. Such a development would be the predicted outcome if indeed the EP has become more institutionalized and professionalized (Yordanova 2011a: 602). 
The introduction is followed by descriptions of the relevance of committee chairs in the institutional architecture of the EP and of the process through which they are appointed. The third section presents the main hypotheses of the study. Next comes a discussion of the research design. A brief section presents the main characteristics of the chairs and the descriptive statistics for the entire sample of MEPs analyzed. I then discuss the results of the multivariate analyses and robustness tests. The conclusion synthesizes the main findings and points to further directions of research.

\section{Why does it matter who chairs an EP committee?}

Committee chairs play an important role in the distribution of reports: together with the party group coordinators they set the value of each report assigned to the committee (Mamadouh \& Raunio 2003: 342). They also work with party group coordinators to decide which experts are invited to committee hearings or whether to commission external reports that would facilitate the achievement of consensus on the bills debated (Daniel and Thierse 2018). Through their influence, chairs acquire more reports than other MEPs, but they are also often 'rapporteurs of last resort' (Yoshinaka et al 2010: 468-469) when no one else wants to write a report.

The conference of committee chairs, first introduced in 1994, also contributes to their salience in the EP legislative process. At this monthly meeting chairs debate 
organizational matters, draft agendas and settle disputes between committees (Judge and Earnshaw 2008: 165).

It is widely accepted that the rapporteur is the single MEP with the most influence over the text of a bill. Nevertheless, committee chairs monitor the 'progress of legislation through the committee cycle' (Judge and Earnshaw 2008: 165) and they can occasionally be the decisive entrepreneurs who ensure the passage of legislation through their committee influence and connections with other relevant EU actors, as happened with the LIBE chairman in the case of the controversial SWIFT agreement (Ripoll Servent 2015).

Yet another important aspect is that the standard operating procedure in some committees was that chairs participate in inter-institutional negotiations - trilogues (Roederer-Rynning and Greenwood 2017). Since 2012, this procedure has been institutionalized by inclusion in the Rules of Procedure: committee chairs became de jure members of the EP negotiating team in trilogues (Roederer-Rynning and Greenwood 2017: 742).

There are also legislative behavior differences between committee chairs and EP backbenchers. The former have privileged access to at least one parliamentary activity that is more constrained procedurally, namely oral questions, whereas they tend to ask fewer written questions (Sorace 2019). 
The capacity to influence policies and the access to parliamentary activities with high visibility described above should make the office of chair particularly appealing - and this is how most MEPs perceive it. In the three waves of surveys (Hix et al 2016) that asked MEP which European Parliament office they would choose out of EP Group President, National Delegation President, President of the EP or Committee Chair, the last option was the first choice of $29 \%$ of the respondents and the second choice of $31 \%$. The cumulative share for the two choices is larger than the corresponding share for each of the other three positions.

Committee chair positions are attractive also because they can be a springboard for other highly prestigious political offices at EU or national level. An illustrative case is that of the French MEP, Joseph Daul, who was virtually unknown before serving for 5 years as chair of AGRI. His performance in this position helped him become the chairman of the EPP-ED group in the EP and then president of the EPP. Other committee chairs went on to become Commissioners (e.g. Viviane Reding) or ministers in national cabinets (e.g. Hedy D'Ancona, Alain Lamassoure). The career advancement of committee chairs is facilitated by their increased news visibility compared to other MEPs (Gattermann and Vasilopoulou 2015: 131)

The allocation of committee chairs among EPGs and the selection of the MEPs who wish to serve in these positions follows three steps (Whitaker 2011: 92). First, the EPGs are assigned the committees for which they may nominate chairs, in the order and 
number that corresponds to their share of MEPs, using the d'Hondt method. ${ }^{2}$ Then, at EPG level, the national parties choose their preferred committees, based on the size of their delegation. Finally, the national parties nominate one of their MEPs to be the chair of the particular committee. Given this complicated system, which puts a premium on proportionality at EPG level and on balance between national delegations, is there any space for policy specialization to influence committee chair selection?

The allocation and selection processes happen behind closed doors but media have been able sometimes to reveal who the aspirants were (Euractiv 2004, Taylor 2014). These accounts reflect the competitiveness of the process, particularly for the most powerful committees, both between EPGs, before the chair positions are allocated, and within the same EPG after the chairmanship is secured.

\section{Theoretical framework}

Studies of committee chair selection outside the US Congress remain rare, even if more attention has been devoted to the topic recently (Santos and Reno 2004; Chiru and Gherghina 2017; Fernandes et al 2019). This is why our theoretical framework is inspired by congressional theories of legislative organization and their adaptations to the EP setting. ${ }^{3}$ Furthermore, the previous analyses of committee chair selection in EP have not tested comprehensively the main predictions of the legislative organization theories. Bowler and Farrell (1995) assessed the effect of committee seniority and EPG 
leadership position but not that of voting loyalty. Kreppel (2002) only analyzed in a bivariate manner whether the voting loyalty towards the EPG and vote attendance rates differ between regular MEPs and those who served several terms as committee chair in the 1979-1996 period. Last but not least, Withaker's analyses (2011) of chair (and vice chair) appointment did not include any factors related to the EPGs.

The informational and partisan theories of legislative organization are the most likely to matter for committee chair selection in EP. The weak electoral connection of the MEPs and the fact that parties (EPGs and national party delegations) control the allocation of parliamentary office makes the distributive approach the least suited of the main Congressional legislative organization theories to explain the selection of EP committee chairs. Nevertheless, in an innovative adaptation of this theory to the EP environment, Yordanova (2009) has shown one prediction of the distributive approach does hold that for interest-driven EP committees ${ }^{4}$ and the main mechanism through which this happens is via ties with interest groups. Thus, her article illustrated that legislators serving in such committees have more radical policy preferences than the median MEP, and that this radicalism goes in the same direction within the committees (i.e. homogenous outlying preferences). However, such committee assignment does not automatically produce legislative outcomes that are incongruent with the preferences of the median legislator or the median party legislator as long as the key positions in a committee follow an informational or a partisan logic of allocation. Indeed, Bowler and 
Farrell (1995) found no evidence that the selection of chairs and deputy chairs would be influenced by ties to interest groups. The same conclusion was reached for the appointment of party group coordinators in committees (Daniel and Thierse, 2018), a position similar to that of chair in terms of the stakes involved for the EPG. Moreover, the inter-partisan and intra-partisan proportionality constraints operating in the allocation and selection of chairs limit significantly the self-selection mechanism proposed by the distributive logic. Given all these elements, this paper focuses solely on the determinants of committee chair selection suggested by the informational and partisan theories.

We know already that having served in a committee before substantially increases the likelihood of an MEP being assigned to that committee again (Yordanova 2009: 271; Whitaker 2019), a finding in line with the expectations of the informational theory. Two studies have tested whether committee seniority increases the chance of being selected as a chair or deputy chair. In their analysis of the 1989-1994 term, Bowler and Farrell (1995: 238) found no evidence that MEPs remaining in the same committee had a better chance to be appointed to the bureau of the committee. On the contrary, Whitaker's analyses (2011: 103) showed that the same variable increased the likelihood of being selected chair or deputy chair in the fifth and sixth terms. Unlike these studies, the current article will not conflate chairs and vice-chairs in the multivariate analyses and will use a continuous measure of committee seniority. 


\section{H.1.: Higher committee seniority increases the likelihood of being appointed committee chair}

If one adopts the informational perspective of committee organization (Gilligan and Krehbiel, 1990), the most efficient usage of legislative resources that also facilitates policy specialization is to nominate as committee chairs MEPs who have played this role in the past. In this way, the technical knowledge accumulated, leadership skills developed and personal relationships formed with other EP or EU leaders are not wasted. Bowler and Farrell (1995: 238) who focused on the third EP term, illustrated that previous members of the committee bureau are more likely to be re-appointed chair or vice-chair. Moreover, this institutional logic of rewarding legislators who have delivered in their roles by re-appointing them to the same position seems to apply to other key EP positions, too, such as the party group coordinators in committees (Daniel and Thierse 2018). Although the policy specialization logic would put a premium on chair seniority in the same committee, the very high turnover in the EP and the proportionality constraints in chair allocation probably lead EPG and national delegation leaders to value highly the leadership skills and legislative process knowledge acquired as chair in any committee.

\section{H.2: Higher chair seniority increases the likelihood of being appointed committee chair}

The partisan perspective maintains that parties act as cartels, using committee assignment and the allocation of committee offices strategically to control the behavior of their members, control the agenda and achieve their policy goals (Cox and 
McCubbins, 1993). One of the empirical predictions of this theory is that parties would exploit committee assignment to reward loyal members and punish those who do not toe the party line at roll-call votes. Several authors have speculated that dissenting against the EPG's voting positions would sideline MEPs for committee chairmanships (Ripoll Servent 2018: 192; Sorace 2019), in a similar manner in which this happens for rapporteurships (Yoshinaka et al. 2010; Yordanova 2011b). As frequent dissenting voting behavior might indicate divergent ideological preferences, EPGs would try to avoid such nominations in order to minimize policy drift. On the contrary, Ringe (2013: 56) maintains, based on interview data, that EPGs cannot oppose the nomination of an MEP as committee chair for not toeing the party line. Nevertheless, the relation between loyalty and chair selection has not been tested comprehensively until now.

H.3: A higher level of loyalty towards the European Party Group increases the likelihood of being appointed committee chair

Another empirical prediction deducible from the partisan theory of committee organization is that parties could maximize their policy influence and monitor the behavior of their committee members by appointing someone from the party leadership as committee chair (Chiru and Gherghina 2017). Party leaders are more aware of the policy objectives of their party than rank and file legislators and they can use control of committee agendas to block proposals their party dislikes or to speed up the legislative process for those bills the party prioritizes. Individual career ambition might be another 
factor at work in this situation. Although previous research has found no evidence that party leaders use their power to ensure their own assignment to the most powerful EP committees (Yordanova 2009: 274), members of the EPG bureaus, who are usually also leaders of their national party delegations, are well-positioned to negotiate and secure for themselves committee chairmanships. Indeed, Bowler and Farrell (1995: 238) emphasized that an EPG leadership position makes appointment as chair or vice-chair more likely.

H.4: An EPG leadership position increases the likelihood of being appointed committee chair In addition to these hypotheses, the models also include five control variables: EP seniority, whether a legislator from the same national party delegation as the MEP was appointed chair in another committee, national delegation size, age and gender. Length of experience in the EP might matter given that 'most committee chairs are allocated to incumbent MEPs' (Hix and Høyland 2014: 599) and more senior MEPs can rely on a network of cross-partisan relations that can be useful for the chair role. They also have a better knowledge of how the EU legislative process works compared to newcomers.

If a national party delegation has nominated already the chair in another committee, the odds for appointing another of its MEPs for a chair position should be slim. MEPs from larger Member States (MS) might have a better chance of getting the seat because they tend to have a bigger say in their EPGs compared to MEPs of smaller nations. Young MEPs might be seen as lacking the necessary experience to chair committees, whereas 
old MEPs might have a prestigious national political career which could trigger more acquiescence from other committee members. I also include a control for gender, since it might be more difficult for women to become chairs, given that male legislators control the distribution of resources in the EP.

\section{Data, indicators and method}

The dependent variable of this study is dichotomous: the MEPs selected to be chairs of the first committee bureaus of the term are coded 1 , while all others are coded 0 . The paper focuses on the first chair elections in each term because the chair re-shuffle that takes place at mid-term is more likely to be influenced by the redistribution of other EP offices, i.e. the 'game of musical chairs' (Whitaker 2011: 93) and to be used to attract national party delegations to different EPGs. An embarrassing situation was the repeating of the committee bureau mid-term elections held in the 6th term: the first elections held on January 15th were repeated in early February, following renegotiations regarding the distribution of other EP offices (Whitaker 2011). These considerations mean that the first chair elections in each term are more appropriate for studying how individual MEPs' attributes influence the process of chair selection. Since the main variables of interest are committee seniority and chair seniority, analyses exclude data from the first term of the EP. 
Committee seniority indicates the number of years that the MEP has been a member of the particular committee before the start of the current term. Chair seniority reveals the number of years the MEP has been chair of any EP committee in the past.

The European party group disloyalty is based on the NOMINATE scores of MEPs, scaled from their roll-call votes (Hix et al. 2007). Like Yordanova (2009) I measure disloyalty as the absolute distance between a MEP's score and the median of her EPG on the first NOMINATE dimension. ${ }^{5}$ The roll-call data pertains to the term in office analyzed, as do other studies analyzing the impact of voting loyalty on committee assignment (Yordanova 2009; Whitaker 2019). Although using roll-call data from the previous term would exclude the possibility of reverse causality, this would also lead to dropping newcomers from the sample, who represent $50 \%$ or more of the MEPs (Whitaker 2014) in each of the terms studied.

EPG leader is a dummy, coded 1 if the MEP was a chair, vice-chair, treasurer or member of the bureau of her party group. The length of EP career is an ordinal variable recording the experience acquired prior to the current term: ' 1 ' indicates the MEP was elected for the first time, '2' that she had some EP experience before but not more than a full term, ' 3 ' that the MEP served for more than one term but not beyond 10 years, and ' 4 ' that the MEP has served for more than 10 years in the past.

National party (NP) nominated other chair is a dummy coded 1 if the national party of the MEP had nominated the chair in at least one other committee at the inaugural bureau 
elections in the term. National delegation size indicates the total number of EP seats allocated to the Member State of the respective MEP in that term. The MEPs' committee membership, committee office and EPG office were retrieved from Høyland et al. (2009).

The most appropriate method for the aim of our analysis and the data structure is the fixed effects conditional logit model (Chamberlain estimator). The fixed effects are for committees to account for the fact that MEPs are nested in panels (the committees) and that each race for a committee chair position has its specificities: the different prestige of the committee, the different number of competitors or potential competitors and the varying characteristics of the MEPs who could be chairs, i.e. the actual committee members which are the choice alternatives. Because of this, it makes sense to compare only the chairs' characteristics with the other members of the same committee who were potential aspirants for the office (Cann, 2008).

Our decision to model chair selection in this way and not to restrict the analyses to the committee members of the EPGs which were actually allocated chair positions is motivated by research aims. Excluding other committee members from the analyses would make it impossible to assess comprehensively whether the leadership experience and expertise existing in the committee across EPGs was used efficiently or not when nominating the chair. Analyzing the extent to which the EP is efficient in its usage of such resources is one of the main research goals of the paper. The analyses comprise 
two steps: first the determinants of chair selection are assessed for each term individually and then the regressions are run on the pooled sample separately for the most powerful committees and for the rest.

\section{Characteristics of the committee chairs and MEPs in the sample}

Overall, 115 committee chairs were elected in the first committee bureau elections over the 6 terms analyzed. Only 8 MEPs appear twice in this sample and, in total, 24 of the chairs had held this position in previous EP terms. Almost three quarters of them belong to the two largest groups: the Socialists (44 chairs) and the Conservative/ European People Party (42 chairs). In third place are the Liberals (ALDE and its predecessors), with 10 chairs, followed by the Communists with 7, and the Greens, Eurosceptic Conservatives ${ }^{6}$ and the European Democratic Group, each with 4 chairs (see Figure A1.1 in the online Appendix for their EPG affiliation by term).

In terms of nationality, the largest group is from Italy (22 chairs), followed by Germany (21), the United Kingdom (19), France (15) and Spain (12). All other national delegations had fewer than 6 chairs in the entire period analyzed. These figures do not tell the full story, as some of these Member States received slightly more chair positions than they would have been entitled to considering their delegation sizes. Thus, Italy got $19.1 \%$ of the chair position whereas its MEPs represent $13.5 \%$ of all MEPs in the six terms, for Germany the corresponding ratio is $18.3 \%$ vs. $15.4 \%$, for UK it is $16.5 \%$ vs. $13.5 \%$, while 
for Spain it is $10.4 \%$ vs. $8.1 \%$. France represents the only case of slight underrepresentation among the big five Member States: only 13\% of the EP committee chairs were French compared to $13.5 \%$ of the MEPs.

A small under-representation of women is observed. Thus, of the 115 chairs, only 28 were women, a proportion almost $6 \%$ smaller than their overall share in the entire sample of MEPs analyzed: $24.3 \%$ versus $29.9 \%$. The 'average' MEP in the sample is a male, almost 51 years old and has been in the EP for less than a full term before the current term. Only approximately 3\% of the MEPs in the sample are committee chairs, whereas the average length of previous experience as chair is 0.1 years. As expected, MEPs tend to be assigned to committees they have been members of before: the average past committee membership duration is 2 years. $14 \%$ of the MEPs in the sample hold an EPG leadership position. Last but not least, the average loyalty of the MEPs in the sample to the European party group is extremely high. For the complete descriptive statistics see the online appendix (Table A1.1).

\section{What determines chair selection in the EP?}

Table 1 presents the results of the fixed effects conditional logistic regressions, run separately for each of the six terms analyzed. All models include fixed effects for EPGs.

There is little support for our first hypothesis: committee seniority increases the 
likelihood of being appointed committee chair in only one of the terms analyzed, the 1999-2004 legislative period.

Table 1: Determinants of committee chair selection per term

\begin{tabular}{lllllll}
\hline & Term 2 & Term 3 & Term 4 & Term 5 & Term 6 & Term 7 \\
\hline Committee seniority & 1.074 & 1.199 & $1.139+$ & 1.095 & 0.989 & 1.048 \\
Chair seniority & $1.667^{*}$ & $1.967^{* * *}$ & $1.299+$ & 1.092 & $1.732^{* *}$ & $1.333+$ \\
EPG disloyalty & 11.580 & 0.725 & 9.733 & 0.003 & 0.001 & \\
EPG leader & $5.953^{* *}$ & $2.808+$ & 0.660 & 0.694 & 0.602 & 0.571 \\
Length of EP career & 1.479 & 0.747 & 1.199 & $2.139^{*}$ & 1.460 & 1.118 \\
NP nominated other chair & $0.040^{* * *}$ & $0.043^{* * *}$ & $0.261^{*}$ & $0.058^{* * *}$ & $0.129^{* *}$ & $0.122^{* * *}$ \\
National delegation size & $1.037^{* *}$ & 1.019 & 1.003 & $1.023^{*}$ & $1.030^{* *}$ & $1.032^{* *}$ \\
Age & 1.001 & 0.994 & 0.981 & 1.046 & $1.068^{*}$ & $1.079^{*}$ \\
Female & $6.095^{*}$ & 0.511 & 0.414 & 0.658 & 0.351 & 1.281 \\
EPG fixed effects? & Yes & Yes & Yes & Yes & Yes & Yes \\
\hline $\mathrm{N}$ & 542 & 662 & 637 & 676 & 799 & 797 \\
McFadden's R ${ }^{2}$ & 0.420 & 0.313 & 0.218 & 0.341 & 0.320 & 0.269 \\
AIC & 104.506 & 127.887 & 141.012 & 113.178 & 128.881 & 136.194 \\
\hline
\end{tabular}

Cell entries are odds ratios; significance levels at: ${ }^{+} \mathrm{p}<0.10,{ }^{*} \mathrm{p}<0.05,{ }^{* *} \mathrm{p}<0.01,{ }^{* * *} \mathrm{p}<0.001$

The strongest and most consistent effect in the models is that associated with chair seniority. Thus, irrespective of the committee the MEP has chaired, one year of past experience as chair increases the likelihood to hold such an office again by $30 \%$ or more in 5 of the 6 legislative periods analyzed.

By and large, it seems that when EPGs and national parties select a chair for a committee they care more about an MEP's general experience in such an office than about the policy specialization acquired while having been a chair in that particular committee before. In alternative models, reported in the online appendix (Table A2.1), 
the 'chair seniority' variable was replaced with a variable that measures chair seniority strictly within the respective committee. This variable had a statistically significant effect in only four of the six terms. Both terms in which there was no significant effect of chair seniority in committee are more recent: the 5th and the 7th, whereas in each of the first three terms analyzed, the effect of the variable is stronger than that of generic chair seniority. This means that whereas in the earlier stages of the EP, policy specialization as chair in a particular committee was a decisive factor in the selection process, later on - as the importance of the EP grew in the EU political system - the leadership skills and the knowledge of the legislative process acquired as chair became more important.

Voting loyalty towards the EPG does not influence committee chair selection in the EP at all. This is consistent with previous analyses on data from earlier terms (Kreppel 2002: 199) which showed that the level of voting loyalty towards the EPG makes no difference for the appointment of committee chairs. Simultaneously, it shows that the pattern of not allocating reports to disloyal MEPs (Yoshinaka 2010; Yordanova 2011b) does not apply for committee chairs. This could be interpreted as evidence that EPGs deliberately try to avoid policy drift from the rapporteurs, while maverick committee chairs would represent less of a threat because of their role as procedural managers.

In an alternative model (see Table A2.2) I replaced this variable with a measure of voting loyalty towards the national party delegation, as national delegation leaders 
could use their influence over the allocation of committee offices to reward loyal MEPs (Yordanova 2011a: 608). The results show that loyalty towards the national party delegation did not affect the nomination of committee chairs in any of the terms, which corroborates a previous finding, based solely on data from the 5th EP term (Whitaker 2011: 104).

There is some support for the fourth hypothesis: EPG leaders were 6 and 3 times more likely than other MEPs to be appointed committee chairs in the second and third terms respectively. However, this effect disappeared later on, in the four other legislative periods analyzed. This could represent evidence that the process of labor division has become accelerated over time, with the increased professionalization of the EP.

Although it goes in the expected direction in 5 of the 6 terms, the variable measuring the length of the EP career does not make a difference to the likelihood of being selected as committee chair, with the exception of the fifth term when legislators with longer careers had a better chance to receive this office. MEPs from national parties that have nominated the chair in at least one other committee are, as expected, considerably less likely to be appointed themselves for this position.

In the last two terms analyzed, older MEPs had a minor advantage compared with their younger colleagues regarding the odds of being appointed chair. We do not find evidence of gender discrimination in the selection of chairs, while the only coefficient that reached conventional levels of statistical significance, that for the second term, 
indicates that women MEPs were 6 times more likely to receive the office than their male counterparts. Finally, MEPs from larger Member States have a better chance of being appointed chairs. This trend continued in the 8th term: 17/20 chairs in 2014 came from the 6 largest MS!

To help visualize the magnitude of the main effect, that of committee chair seniority, I ran a conditional logit on the pooled data set, including all the six terms analyzed ${ }^{7}$. I computed predictive margins and then transformed them with the esetran command. Figure 1 displays the results with 95\% confidence intervals.

\section{Figure 1: Probability of being appointed chair depending on chair seniority}

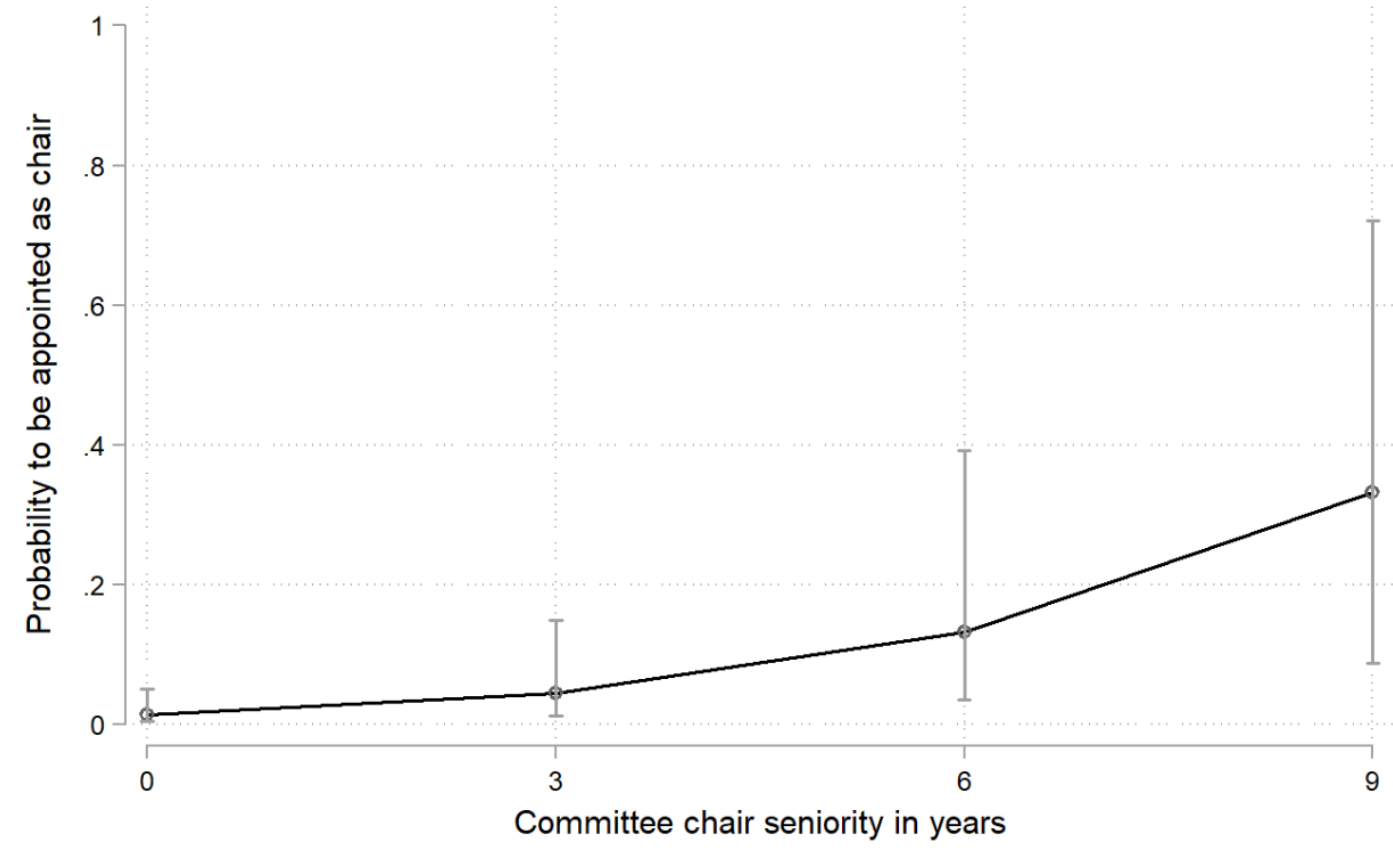

I also ran rare events logistic regressions separately on the samples of the largest EPGs:

S\&D and EPP (see Table A2.3) to investigate whether organizational or ideological 
differences between the party groups influence the relations revealed for the entire sample. Similarly to the findings in Table 1, chair seniority matters greatly in both groups, while voting loyalty does not make any difference. Significant differences also emerge: unlike the social-democrats, the EPP rewards committee seniority and allocates a disproportionate share of its chair positions to MEPs who are part of the group's leadership.

Chair selection in the most powerful committees and in the rest

Not all EP committees are equally capable of influencing policies or affecting legislative outcomes. Hence, I classify them as more powerful or less powerful, by drawing on previous analyses which have measured the committees' legislative output, in terms of legislative involvement and their influence over the EU budget (Yordanova 2009: 256; Whitaker 2011: 31; European Parliament 2014; Ripoll Servent 2018: 249). These sources allow to distinguish between diachronic changes. The threshold for legislative activity used in the classification is whether the committee was involved in at least $5 \%$ of the cooperation or co-decision reports in that term. This dynamic classification does not claim to capture the overall saliency of the committees or their prestige. These criteria would have generated a different categorization. 
The list of more powerful committees comprises: AGRI (from 2009), BUDG, LIBE (from 2004), CULT (from 1994), ECON, EMPL (1989-2009), ENVI, ITRE, IMCO, INTA (from 2009), JURI and TRAN (from 1989).

The category of less powerful committees includes: AGRI (before 2009), CONT, LIBE (before 2004), AFCO, CULT (before 1994), DEVE, EMPL (before 1989, after 2009), PECH, AFET, AFIN, INTA (before 2009), REGI (with the exception of the 1999-2004 term when it also included the Transport and Tourism jurisdiction), PETI, TRAN (before 1989) and FEMM.

The first two regressions in Table 2 focus on the sample of powerful committees, while the last two on the rest. For each pair, the first model includes only the data from the 2nd to the 6th term, while the second model is run on all 6 legislative periods, omitting the EPG disloyalty variable. I include term fixed effects to ensure that the results are not driven by time effects. The findings largely corroborate the results presented in Table 1 . Chair seniority matters for both types of committees in all model specifications, and is the only main effect that achieves this consistent effect. The effect size is rather similar, irrespective of committee output and budgetary powers.

A longer record of committee membership does not increase the chance of being selected as a chair irrespective of the committee type. EPG leaders are more likely to become chairs than regular MEPs only in the case of less powerful committees. 
Table 2: Determinants of chair selection by committee type

Powerful Powerful Less powerful Less powerful

\begin{tabular}{lllll} 
& $(1)$ & $(2)$ & $(1)$ & $(2)$ \\
\hline Committee seniority & 1.045 & 1.072 & 1.068 & 1.030 \\
Chair seniority & $1.560^{* * *}$ & $1.532^{* * *}$ & $1.535^{* * *}$ & $1.478^{* * *}$ \\
EPG disloyalty & 20.610 & & 0.055 & \\
EPG leader & 0.961 & 0.827 & $2.462^{* *}$ & $2.201^{*}$ \\
Length of EP career & $1.749^{*}$ & $1.563^{*}$ & 1.143 & 1.161 \\
NP nominated other chair & $0.085^{* * *}$ & $0.083^{* * *}$ & $0.130^{* * *}$ & $0.137^{* * *}$ \\
National delegation size & $1.025^{* *}$ & $1.029^{* * *}$ & $1.014^{*}$ & $1.016^{* *}$ \\
Age & 1.021 & 1.029 & 1.016 & $1.027+$ \\
Female & 0.689 & 0.611 & 0.601 & 0.920 \\
Term fixed effects? & Yes & Yes & Yes & Yes \\
EPG fixed effects? & Yes & Yes & Yes & Yes \\
\hline N & 1487 & 2012 & 1829 & 2240 \\
McFadden's R & 0.319 & 0.321 & 0.195 & 0.185 \\
AIC & 301.688 & 381.096 & 446.406 & 531.854 \\
\hline
\end{tabular}

Cell entries are odds ratios; significance levels at: ${ }^{+} \mathrm{p}<0.10,{ }^{*} \mathrm{p}<0.05,{ }^{* *} \mathrm{p}<0.01,{ }^{* * *} \mathrm{p}<0.001$

The level of EPG disloyalty does not influence the chair selection process, irrespective of the type of committee under consideration while a longer history of service in the EP increases an MEP's likelihood of being selected as chair in the more powerful committees. MEPs from larger MS have higher probabilities to chair both types of committees, whereas the penalizing effect of the national party nominating the chair in another committee is also present in both. Older MEPs seem more likely to chair less powerful committees and, again, there is no evidence of gender discrimination.

\section{Robustness checks}


I first re-ran the term-by-term regression analyses presented in Table 1 for the mid-term chair elections (see Table A2.4 in the appendix). The chair seniority variable was the best predictor of the outcome in the mid-term elections held in each of the six legislative periods analyzed and its effect was stronger in each of these terms compared to that registered in the elections held at the start of the legislative period. The only other variable that reached statistical significance in all the regressions was the one indicating whether the national party of the MEP nominated the chair in another committee. Committee seniority did not make any difference for the likelihood of being selected chair at mid-term and neither did the party leadership dummy.

Then, I created a pooled sample, including only the MEPs of those EPGs that had actually received the right to appoint the committee chairman. Running the two conditional fixed effects logit models (with and without the EPG disloyalty variable) on this pooled sample corroborated the importance of chair seniority and of two control variables: the dummy indicating whether the national party delegation of the MEP got to nominate the chair in another committee and the variable measuring the size of the national delegation (see Table A2.5).

Another robustness test was to run the models only on the sample of incumbents in order to assess how their lagged EPG disloyalty scores affected their chance of being selected as chairs (see Table A2.6). This variable did not reach conventional levels of statistical significance either, while none of the other main effects was affected. 
Finally, some of the additional predictions of the informational and distributive theories of committee organization could be tested for a smaller sample of MEPs. Thus, drawing on data for the 5th and 6th term MEPs (Whitaker 2011) I could add to the models the sector knowledge of the MEPs (based on their profession and education), their relevant ministerial experience, and whether they had ties with special interests that were relevant for the committee. None of these factors made a difference for chair selection in the two terms (see Table A2.8). While no evidence was found for the tested distributive theory predictions, one could argue that the salience Member States assign to certain committees due to their national interests still plays a role in chair allocation. This could explain why the Regional Development has always been chaired in the past three terms by an MEP from a country which benefits heavily from the Cohesion Policy.

\section{Conclusion}

Our results indicate that the informational theory of committee organization is best suited to predict committee chair selection in the EP, while there is little evidence in favor of the partisan theory. In this respect chair appointment seems to conform to a logic of office allocation also observed for rapporteurships: it mainly serves the informational needs of the EPGs and a premium is put on experience in the role, acquired in the EP and less so on pure policy expertise (Hermansen 2018; Daniel 2015). 
Beyond the informational advantages, a positive implication of selecting experienced chairs is that such a strategy can help develop and maintain a consistent role and image of the committee both for MEPs and outsiders. This was the case for ENVI which became a champion of environmental causes under the 15 years leadership of Ken Collins or for AFET, as its image and prestige were shaped by the 18 years in which Elmar Brok was its chair (Ripoll Servent 2018: 51). On the other hand, too little turnover regarding who chairs the committees could bring autarchic, rigid and narrow-minded leadership but the vast majority of EP committees are very far from such a scenario.

The analyses conducted on our longitudinal sample also illustrated that there does not seem to be a diachronic increase in the relevance of committee seniority or chair seniority for chair selection - which one might have expected, given the growing role of the EP in EU legislative politics and the associated higher stakes for using the legislature's resources effectively. This is particularly problematic since in many policy fields the EP's empowerment with the extension of co-decision has led to the need to compromise and accept frequently suboptimal policy outcomes, which go against positions and preferences EP committees have defended for long time (Ripoll Servent 2018: 271). Because of this, having experienced chairs who know how to play the codecision game, how to act in trilogues and other settings is crucial for the EP to make the most out of its formal empowerment. 
One direction of further research could be to analyze whether MEPs from governing parties started having a higher chance to become chair after the development of EU bicameralism, as Høyland (2006) argues to be the case with rapporteurs. Thus, EP actors' need to forge coalitions with the Council of Ministers could favor the selection as chairs of MEPs affiliated with parties represented there.

\section{Word count: 7208}

Supplemental data for this article can be accessed at [link to source - publisher will add doi at proof]

$\underline{\text { Statistical replication materials and data }}$

Supporting data and materials for this article can be accessed at: https://doi.org/10.7910/DVN/X92POA

Mihail Chiru is a MOVE-IN Postdoctoral Fellow at ISPOLE, UCLouvain, Place Montesquieu, 1, B-1348 Louvain-la-Neuve, Belgium, mihail.chiru@uclouvain.be 


\section{Acknowledgment}

The author is grateful to Tom Delreux, Monika Mühlböck, Olivier Rozenberg, Matt Hann and the three anonymous reviewers for their comments and suggestions on earlier drafts.

\section{Funding}

This work was supported by UCLouvain through the 'MOVE-IN Louvain' Incoming

Post-doctoral Fellowship, co-funded by the Marie Curie Actions of the European Commission. 
${ }^{1}$ According to this perspective the coordination between MEPs of the same EPG who are members of the committee would ensures that despite delegation of policy-making authority to strong committees the partisan policy objectives are still pursued and realized (Ringe 2010: 8-11).

${ }^{2}$ Example: at the beginning of the third term, PES, the largest party, nominated the chair for the first, third, fifth, seventh, ninth, twelfth, fifteenth and seventeenth committees. The second largest party, the EPP received the second, fourth, eighth, eleventh and eighteenth committees, while 3 other groups, LDR, ED and GUE were entitled to nominate the chair in the 5 remaining committees (McElroy 2001)

${ }^{3}$ For comprehensive reviews of these theories and how they fare in the EP context see Martin (2014) and Martin and Mickler (2019).

${ }^{4}$ Committees that have a distributive output: EMPL, AGRI, PECH, REGI.

${ }^{5}$ For terms 2 to 5, the NOMINATE scores are computed based on all roll-call votes, while for the 6th term only roll-call votes from the first year of the term were available. The absence of roll-call vote data for the 7th term led to excluding the EPG loyalty variable from the corresponding regression.

${ }^{6}$ This includes the European Conservatives and Reformists, European Democratic Alliance, European Progressive Democrats, Union for Europe of the Nations.

${ }^{7}$ This model included term fixed effects. 


\section{References}

Bowler, S. and Farrell, D. (1995) 'The Organizing of the European Parliament: Committees, Specialization and Co-ordination', British Journal of Political Science, 25.2: $219-43$.

Cann, D. M. (2008) 'Modeling committee chair selection in the US House of Representatives', Political Analysis 16.3: 274-289.

Chiru, M., and Gherghina, S. (2017). 'Committee chair selection under high informational and organizational constraints', Party Politics, First View, DOI: 1354068817741765.

Cox, G. and McCubbins, M. (1993). Legislative Leviathan: Party Government in the House. Berkeley: Cambridge University Press

Daniel, W. (2015). Career behaviour and the European parliament: All roads lead through Brussels?. Oxford: Oxford University Press.

Daniel, W. and Thierse, S. (2018) 'Individual Determinants for the Selection of Group Coordinators in the European Parliament', Journal of Common Market Studies, 56.4: 939-954.

Fernandes, J. M., Riera, P., and Cantú, F. (2019). The Politics of Committee Chairs Assignment in Ireland and Spain. Parliamentary Affairs 72.1: 182-201. 
Gattermann, K. and Vasilopoulou, S. (2015) 'Absent yet popular? Explaining news visibility of Members of the European Parliament', European Journal of Political Research 54.1: 121-140.

Gilligan, T., and Krehbiel, K. (1990) 'Organization of informative committees by a rational legislature', American Journal of Political Science 34.2: 531-564.

Hermansen, S.S.L. (2018) '(Self-) selection and expertise among decision-makers in the European Parliament', The Journal of Legislative Studies 24.1: 148-172.

Hix, S., Noury, A. G. and Roland, G. (2007). Democratic politics in the European Parliament. Cambridge: Cambridge University Press.

Hix, S., and Høyland, B. (2014). 'Political behavior in the European Parliament' in S. Martin, T. Saalfeld and K. Strøm (Eds.), The Oxford Handbook of Legislative Studies. Oxford: Oxford University Press, 592-605

Hix, S., Farrell, D., Scully, R., Whitaker, R. and G. Zapryanova (2016) 'EPRG MEP Survey Dataset: Combined Data 2016 Release', http://www.mepsurvey.eu/dataobjects/data

Høyland, B. (2006) 'Allocation of codecision reports in the fifth European Parliament', European Union Politics 7.1: 30-50.

Høyland, B., Sircar, I. and Hix, S. (2009) 'An Automated Database of the European Parliament' European Union Politics 10.1: 143-152. 
Hurka, S. and Kaeding, M. (2012) 'Report allocation in the European Parliament after eastern enlargement', Journal of European Public Policy, 19.4: 512-529.

Judge, D. and Earnshaw, D. (2008) The European Parliament. Basingstoke: Palgrave Macmillan.

Kreppel, A. (2002) The European Parliament and Supranational Party System: a study in institutional development, Cambridge: Cambridge University Press.

Mamadouh, V. and Raunio, T. (2003) 'The committee system: powers, appointments and report allocation', JCMS: Journal of Common Market Studies 41.2: 333-351.

Martin, S. (2014) 'Committees', in: S. Martin, T. Saalfeld and K. Strøm (Eds.), The Oxford Handbook of Legislative Studies, Oxford: Oxford University Press, 352-368.

Martin, S., and Mickler, T. (2019) 'Committee Assignments: Theories, Causes and Consequences', Parliamentary Affairs 72.1: 77-98.

McElroy, G. (2001) ‘Committees and Party Cohesion in the European Parliament', EPRG Working Papers 8, available at: http://www2.lse.ac.uk/government/research/resgroups/EPRG/pdf/workingPaper 8.pdf.

Ringe, N. (2010) Who decides, and how?: Preferences, uncertainty, and policy choice in the European Parliament. Oxford: Oxford University Press.

Ripoll Servent, A. (2015) Institutional and policy change in the European parliament: Deciding on freedom, security and justice. Basingstoke: Palgrave Macmillan. 
Ripoll Servent, A. (2018) The European Parliament. Basingstoke: Palgrave Macmillan.

Roederer-Rynning, C. and Greenwood, J. (2017) 'The European Parliament as a developing legislature: coming of age in trilogues?', Journal of European Public Policy 24.5: 735-754.

Santos, F., and Renno, L. (2004) 'The selection of committee leadership in the Brazilian Chamber of Deputies', The Journal of Legislative Studies 10.1: 50-70.

Taylor, S. (2014) 'Reding to miss out on chair of legal affairs committee', Politico. Available at: https://www.politico.eu/article/reding-loses-legal-affairs-chair-toczech-epp-mep/

Sorace, M. (2019) 'Legislative Participation in the EU: An analysis of questions, speeches, motions and declarations in the 7th European Parliament', European Union Politics 19.2: 299-320.

Whitaker, R. (2011). The European Parliament's Committees: National party influence and legislative empowerment. London: Routledge.

Whitaker, R. (2014) 'Tenure, turnover and careers in the European Parliament: MEPs as policy-seekers', Journal of European Public Policy, 21.10: 1509-1527.

Whitaker, R. (2019) 'A Case of 'You Can Always Get What You Want'? Committee Assignments in the European Parliament', Parliamentary Affairs 72.1: 162-181 
Yordanova, N. (2009) 'The rationale behind committee assignment in the European Parliament: Distributive, informational and partisan perspectives', European Union Politics 10.2: 253-280.

Yordanova, N. (2011a) 'The European Parliament: In need of a theory', European Union Politics 12.4: 597-617.

Yordanova, N. (2011b) 'Inter-institutional rules and division of power in the European Parliament: allocation of consultation and co-decision reports', West European Politics 34.1: 97-121.

Yoshinaka, A., McElroy, G. and Bowler, S. (2010) 'The appointment of rapporteurs in the European Parliament', Legislative Studies Quarterly 35.4: 457-486.

*** Euractiv. (2004) 'New EP committee chairmen unveiled'. Available at: https://www.euractiv.com/section/elections/news/new-ep-committee-chairmenunveiled/

*** European Parliament. (2014). 'Activity Report on Codecision and Conciliation during the 7th legislative term (14 July 2009-30 June 2014)'. 